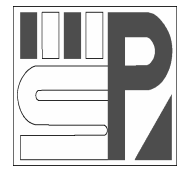

Science Press
Journal of Arid Land

2011, 3(4): 303-305

doi: 10.3724/SP.J.1227.2011.303

jal.xjegi.com; www.chinasciencejournal.com

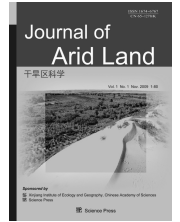

\title{
Fauna of Heteroptera in the deserts of Kazakhstan
}

\author{
Yesenbekova Perizat Abdykairovna* \\ Institute of Zoology, Akademgorodok 050060, Kazakhstan
}

\begin{abstract}
Heteroptera is an important group among the insect orders, not only for its number of species, but also for its distribution and food preference. A total of 405 species of Heteroptera were identified in the desert areas of Kazakhstan, in which 158 species are distributed in the sandy deserts, 105 species in the Solonchak deserts, 75 species in the clay deserts, and 67 species in the rocky-rubbly deserts.
\end{abstract}

Keywords: fauna; heteroptera; desert; Kazakhstan

Heteroptera is one of the most peculiar orders of insects, inhabiting very diverse biotopes and playing an important role in the biological processes of biogeocoenoses (Schuh, 1995; Fauvel, 1999). The biology and cataloging of Heteroptera were studied in the United States and Britain (Butler, 1923; Henry and Froeschner, 1988). The basis of the given research was provided by the author's collection and field observation, as well as the Heteroptera collection of Kazakhstan, stored in the Institute of Zoology of the Ministry of Education and Science of Kazakhstan. The collection of the author's field work was carried out from 1998 to 2009 in different regions of Kazakhstan. The desert land of Kazakhstan occupies a large area and accounts for about $44 \%$ of the total territory (Mirhashimov, 2005). According to the soil conditions and vegetation regime, the desert landscapes are subdivided into sandy, solonchak, clay and rocky-rubbly deserts.

\section{Sandy desert group}

The sandy deserts of Kazakhstan occupy $33.6 \times 10^{4}$ $\mathrm{km}^{2}$, which accounts for $30 \%$ of the total desert territory of the Republic (Mirhashimov, 2005). In sandy deserts, most heteropterans have a hidden lifestyle in the soil, near the roots, in plant underlayers. This hidden lifestyle is caused by the necessity to adapt to the environments of a serious water deficiency. Vegetation and soil protect heteropterans from direct sunlight.

Most phytophagous heteropterans live in the plants' underlayer and near the roots. They include the species of families Pentatomidae: Sciocoris deltocephalus, Sciocoris sulcatus, Putonia asiatica; Scutelleridae: Phimodera amblygonia, Phimodera fumosa, Ph. bergi, Odontotarsus angustatus, Odontotarsus impictus, Odontotarsus obsoletus, Irochrotus lanatus, Irochrotus turanicus; Coreidae: Phyllomorpha lacerata; and Lygaeidae: the species of genera Geocoris, Emblethis, and Blissus putoni. The fauna of sandy deserts includes 158 species of Heteroptera and its habitat is of xerophiles, inhabiting the typical plants of sandy deserts. In terms of species diversity, the dominating families include Lygaeidae, 30 species (19\%); Pentatomidae, 23 (14.5\%); Cydnidae, 19 (12\%); Miridae, 17 (10.7\%); Scutelleridae, 16 (10.1\%); Reduviidae, 14 (8.9\%); Tingidae, 12 (7.6\%); Rhopalidae, 11 (7\%), and the other 7 families are represented by only $1-4$ species. The group zoogeographically consists of Iran-Turan, Turan and Tethys species, also a polyzonal cosmopolite Liorhyssus hyalinus was recorded, as well as Holarctic species Nysius thymi, Kalama tricornis, Empicoris culiciformi, Ethiopia-TranspalaearcticOriental Microporus nigrita, Transpalaearctic-Oriental

Received 2011-02-13; accepted 2011-06-24

*Corresponding author: Yesenbekova Perizat Abdykairovna (E-mail: esenbekova_periz@mail.ru) 
Geocoris pallidipennis, Transpalaearctic Brachyca renustigrinus, Byrsinus flavicornis, Odontoscelis fuliginosa, Brachynema germari, Tingis pauperata, Western Palaearctic-Ethiopian Odontoscelis dorsalis, Tethys-Ethiopian Hyalocoris pilicornis, Aethus hispidulus and A. pilosus. Endemics and subendemics of sandy deserts include the Turan endemic species Ploiaria turkestanica, Cercinthinus annulipes, Holotrichius ilius, and Turan subendemic species Holotrichius bergrothi, Vachiria semenovi.

\section{Solonchak desert group}

Solonchak deserts are formed in the depressions of relief, with the deposits of salty subterranean waters. Landscapes of solonchak deserts may be observed at maritime on the low-lying plains of Caspian and Aral seas on the bottom of lake basins and depressions (Mynbulak in Kyzylkum). The solonchak desert group is represented by 105 species from 12 families, connected to solonchak and solonetz. Dominating families in this group include Miridae, 26 species (24.7\%); Lygaeidae, 22 (21\%); Pentatomidae, 17 (16.2\%); and the other 9 families are represented by only $1-8$ species. Characteristic habitats of heteropterans include river terraces, deltas, as well as numerous salty areas of sandy deserts. The group is represented mainly by halophiles. A heteropteran background of the given group is developed by the following species: Tarisa elevata, T. pallescens, T. salsae, Brachynema signatum, Desertomenida albula, Trigonotylus ruficornis, Artheneis alutacea, A. intricata, Nysius thymi, Henestaris halophilus, Engistus salinus, Agramma atricapillum. Zoogeographically, the group is represented mainly by the Turan (36\%), Iran-Turan (28\%), and Tethys $(25 \%)$ species. Sometimes one may be recorded in Western Palaearctic-Oriental, Byrsinus pilosulus; Western Palaearctic, Artheneis alutacea, Geotomus elongatus; and Turkestan-Northern Turan endemic, Tuponia suturalis.

\section{Clay desert group}

Clay deserts (takyrs) are flat areas, with heavy soil bottoms, without vegetation. Takyrs are distributed separately, or in sheets, and their clay surface is almost waterproof. In Kazakhstan, clay deserts occupy a vast of area in Ustyurt, Priaralye, Betpakdala and Pribalk- hashye, Talasskiy Alatau and the Karatau foothills. The species composition of eco-fauna in the clay desert is noticeably less in comparison with eco-fauna of the sandy desert. This group consists of 75 species from 10 families. Among them, the species of family Miridae is diverse with 22 species (29.3\%), Lygaeidae and Tingidae with 10 species each (13.3\%), Pentatomidae with 8 species $(10.7 \%)$, and the other 6 families are represented by only $2-6$ species. The species, inhabiting clay desert, are Artemisia, Salsola, Ephedra, Krascheninnikovia. Zoogeographically, they belong to the Iran-Turan (20\%), Turan (12\%), Tethys (19\%), Scythian (6\%), Transpalaearctic (9\%), Western Palaearctic (19\%), Eastern Palaearctic (5\%), and Eurasian (about 10\%) species.

\section{Rocky-rubbly desert group}

Rocky-rubbuly deserts are formed in low, melkosopochnik mountains, and in the upper parts of foothill plains, which are formed as a result of mountain rock destruction, thus covered by a "rocky coat", often being a residual soil. Rocky deserts are mainly covered by lichens and desert moss, known as Artemisia and Salsola. Heteropterans have quite small numbers in the rocky-rubbly desert, and are recorded in the spots on plains and on the trails of dry, low mountains. All the species are concentrated in small relief eminences, where water and small shrub vegetation have developed. The group is poor not only in flora, but also in fauna. In the clay desert group only 67 species from 10 families were recorded. The leading family among them is family Lygaeidae, 32 species (48\%), and the other 9 families are represented by only 1-6 species. Due to severe climatic conditions of this desert type, many heteropterans adapt to the life at the plant roots or in the underlayer, but rarely under stones. This group of specific detritophages includes all the species of genera Emblethis, Geocoris, Xanthochilus and some species of family Cydnidae. Predators include, for instance, Reduvius testaceus, Coranus subapterus, Oncocephalus albicostatus, and Vachiria prolixa. Predators Holotricius bergrothi, and Reduvius disciger live under rocks and eat spiders and small invertebrates, including caterpillars of different butterflies. Zoogeographically, the dominating species includes Turan, Iran-Turan, and Tethys ones. Nineteen species (28\%) were recorded in the wider Palaearctic distribu- 
tion areas. Two species (Lygus rugulipennis, Polymerus cognatus) are in the Holarctic area, two species (Nysius cymoides, Plinthisus ptilioides) in the Western Palae-arctic-Ethiopian area, two species (Oxycarenu spallens, Camptocera glaberrima) Ethiopian-Western Palaearctic-Oriental area and one species (Microplax interrupta) Western PalaearcticOriental area.

\section{Eurytopic desert group}

This group consists of 31 species, recorded in different types of deserts. Dominating species of this group include eurytopous xerophiles, oligophagous, and to a lesser extent-polyphage (associated with Artemisia), Atraphaxis, legumes, cereals: Geocoris desertorum, Geocoris erythrocephalus, Graptopeltus validus, Camptocera glaberrima, Proderus bellevoyei, Diomphalus hispidulus, Armenoecus testaceus, Hadrocnemis diversipes, Hadrocnemis albomaculata, Plinthisus soongoricus, Plinthisus reyi, Pionosomus horvathi, Icus angularis, Stictopleurus angustus, Ceraleptus obtusus, Aethus hispidulus, Irochrotus turanicus, Odontoscelis zarudnyi, Odontoscelis byrrhus, Odontoscelis dorsalis, Odontoscelis fuliginosa, Brachynema germarii, and Tingis biseriata, Tingis grisea. In term of predators there are Nabis palifer, Nabis sinoferus, Holotrichius bergrothi, Holotrichius tristis, Pasira basiptera,

\section{References}

Butler E A. 1923. A Biology of the British Hemiptera-Heteroptera. London: H.F. and G. Witherby.

Fauvel G. 1999. Diversity of Heteroptera in agroecosystems: role of sustainability and bioindication. Agriculture, Ecosystems and Environment. 74(1-3): 275-303.

Henry T J, Froeschner R C. 1988. Catalog of the Heteroptera, or True Bugs, of Canada and the Continental. United States. New York: E. J.
Rhynocoris monticola, Rhynocoris nigronitens. These species are characterized by the Kazakhstan-Northern Turan, Iran-Turan and Turan types of distribution areas, whereas, the wider Palaearctic distribution areas have Transpalaearctic species Brachynema germari, Odontoscelis fuliginosa, Western Palaearctic-Ethiopian Odontoscelis dorsalis, and Middle Tethys-Oriental Irochrotus turanicus.

\section{Conclusion}

A total 405 species of Heteroptera were identified in desert areas of Kazakhstan. In relation to zoogeography, the dominating species are the Turan, Iran-Turan and Tethys species. The sandy desert group is rich in species composition (158 species), and the habitat is distributed by xerophiles. The solonchak desert group is represented by 105 species from 12 families, associated with solonchak and solonetz habitats. Heteropterans of the clay desert are the most diverse. This group consists of 75 species from 10 families, distributed in dry loess plains and interhill valleys with ephemers and ephemeroids. In the rocky-rubbly deserts, Heteroptera are observed in the spots on the plains and on the trails of dry low mountains, and are quite small in numbers. This group consists of 67 species from 10 families.

Brill.

Mirhashimov L. 2005. Landscape and biological diversity of the Republic of Kazakhstan. Informacionno-analiticheshiy obzor Programmy Razvitiya OON Almaty: OO "OST-XX century", 242.

Schuh R T, Slater J Z. 1995. True Bugs of the World (Hemiptera: Heteroptera). New York: Cornell University Press. 